Article

\title{
Enantioselective Protonation of Radical Anion Intermediates in Photoallylation and Photoreduction Reactions of 3,3-Diaryl-1,1-dicyano-2-methylprop-1-ene with Allyltrimethylsilane
}

\author{
Hajime Maeda *, + D, Masayuki Iida, Daisuke Ogawa and Kazuhiko Mizuno * \\ Department of Applied Chemisty, College of Engineering, Osaka Prefecture University, 1-1 Gakuen-cho, \\ Naka-ku, Sakai, Osaka 599-8531, Japan \\ * Correspondence: maeda-h@se.kanazawa-u.ac.jp (H.M.); kmizunophotochem@gmail.com (K.M.); \\ Tel./Fax: +81-76-264-6290 (H.M.) \\ + Present address: Division of Material Chemistry, Graduate School of Natural Science and Technology, \\ Kanazawa University, Kanazawa, Ishikawa 920-1192, Japan.
}

Academic Editor: Yasuharu Yoshimi

Received: 25 June 2019; Accepted: 22 July 2019; Published: 23 July 2019

\begin{abstract}
Photoreactions of acetonitrile solutions of 3,3-diaryl-1,1-dicyano-2-methylprop-1-enes (1a-c) with allyltrimethylsilane (2) in the presence of phenanthrene as a photoredox catalyst and acetic acid as a proton source formed photoallylation (3) and photoreduction (4) products via photoinduced electron transfer pathways. When (S)-mandelic acid was used as the proton source, the reactions proceeded with 3.4 and $4.8 \%$ ee for formation of 3 and $\mathbf{4}$, respectively. The results of studies of the effect of aryl ring substituents and several chiral carboxylic acids suggested that the enantioselectivities of the reactions are governed by steric controlled proton transfer in intermediate complexes formed by $\pi-\pi$ and $\mathrm{OH}-\pi$ interactions of anion radicals derived from $\mathbf{1 a}-\mathbf{c}$ and chiral carboxylic acids.
\end{abstract}

Keywords: photoreaction; photoinduced electron transfer; photoredox catalyst; Felkin-Anh model; radical anion; electron deficient alkene; allylsilane; mandelic acid; enantioselectivity; enantiomer

\section{Introduction}

Coupling reactions proceeding through photoinduced electron transfer (PET) pathways have been extensively studied from both a synthetic as well as a mechanistic viewpoint [1-14]. Because radical ions that serve as intermediates in these processes are short-lived and highly reactive, control of the stereochemistry of these reactions is often difficult [15-21]. We have previously developed photoallylation and photoreduction reactions of electron deficient alkenes with allyltrimethylsilane that occur via PET pathways [22-24]. In addition, we also demonstrated that diastereoselectivity of this process can be achieved by steric control of allyl radical or proton addition to radical anions that are generated from electron deficient alkenes (Scheme 1) [25-27]. The current study was aimed at the development of enantioselective PET promoted coupling reactions, and specifically, at assessing the effect of chiral carboxylic acids on the stereochemical outcomes of photoallylation and photoreduction reactions of prochiral electron deficient alkenes. The results showed that these processes took place with maximum 3.4-4.8\%ee when (S)-mandelic acid was used as the chiral proton source. 
<smiles>[R]C1CCc2ccccc2C1=C(C#N)C#N</smiles>

ref. 25<smiles>[R]C1CCCCC1=C(C#N)C#N</smiles>

ref. 26<smiles>C/C(=C(\C#N)C(C)c1ccccc1)c1ccccc1</smiles>

ref. 27

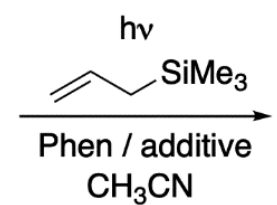

Phen $=$ phenanthrene
Photoallylation and photoreduction via PET

$94 \%$ de (ref. 25)

$90 \%$ de (ref. 26)

$\sim 72 \%$ de (ref. 27 )

Scheme 1. Our previous works.

\section{Results and Discussion}

Irradiation of an acetonitrile solution containing 1,1-dicyano-2-methyl-3,3-diphenylprop-1-ene (1a), 3 equiv of allyltrimethylsilane (2), a catalytic amount of phenanthrene (Phen) as a photoredox catalyst in a Pyrex vessel using a $300 \mathrm{~W}$ high-pressure mercury lamp was found to produce reduction product 4a in 53\% yield (Scheme 2, Table 1, entry 1, supplementary). Photoreaction of 1a with 2 in the presence of acetic acid produced the allylated product 3a in addition to $4 \mathbf{a}$ in 34 and $31 \%$ yields, respectively (entry 2 ). The corresponding products $3 \mathbf{b}-\mathbf{c}$ and $\mathbf{4 b - c}$ were produced in photoreactions of bis(p-methoxyphenyl) (1b) and bis(p-chlorophenyl) (1c) derivatives conducted under the same conditions (entries 3-6). The irradiation times used for these processes are those required for complete consumption of $\mathbf{1 a}-\mathbf{c}$. The observed efficiencies of the reactions, based on the required irradiation times, decreased in the order $\mathbf{1} \mathbf{c}>\mathbf{1 a}>\mathbf{1 b}$.
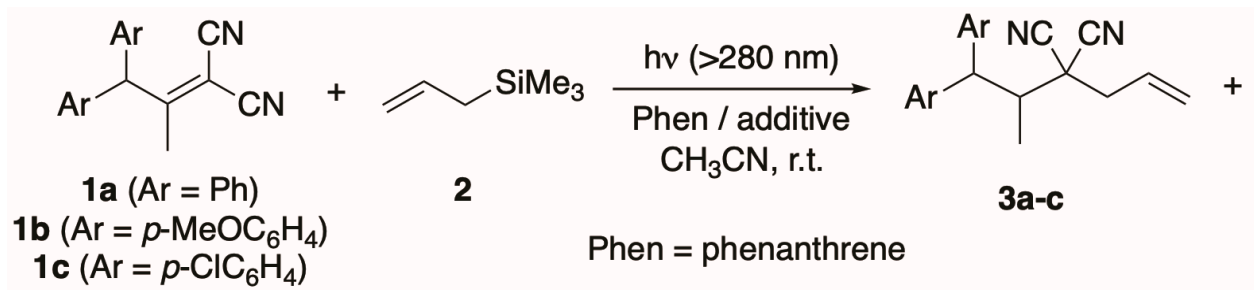<smiles>CC(Br)C(C#N)C(C)C(Br)Br</smiles>

Phen $=$ phenanthrene

Scheme 2. Photoallylation and photoreduction of $1 \mathrm{a}-\mathrm{c}$ by using allyltrimethylsilane (2).

Table 1. Photoallylation and photoreduction of $1 \mathrm{a}-\mathrm{c}$ by using allyltrimethylsilane (2) ${ }^{\mathrm{a}}$.

\begin{tabular}{cccccc}
\hline \multirow{2}{*}{ Entry } & Substrate & Additive & $\begin{array}{c}\text { Irradiation } \\
\text { Time/h }\end{array}$ & \multicolumn{2}{c}{ Yields/\% } \\
\cline { 5 - 6 } & & & $\mathbf{3}$ & $\mathbf{4}$ \\
\hline 1 & $\mathbf{1 a}(\mathrm{Ar}=\mathrm{Ph})$ & none & 4 & $0^{\mathrm{b}}$ & $53^{\mathrm{b}}$ \\
2 & $\mathbf{1 a}(\mathrm{Ar}=\mathrm{Ph})$ & acetic acid $\mathrm{c}$ & 4 & $34^{\mathrm{b}}$ & $31^{\mathrm{b}}$ \\
3 & $\mathbf{1 b}\left(\mathrm{Ar}=p-\mathrm{MeOC}_{6} \mathrm{H}_{4}\right)$ & none & 24 & $0^{\mathrm{d}}$ & $44^{\mathrm{d}}$ \\
4 & $\mathbf{1 b}\left(\mathrm{Ar}=p-\mathrm{MeOC}_{6} \mathrm{H}_{4}\right)$ & acetic acid $^{\mathrm{c}}$ & 24 & $20^{\mathrm{d}}$ & $46^{\mathrm{d}}$ \\
5 & $\mathbf{1 c}\left(p-\mathrm{ClC}_{6} \mathrm{H}_{4}\right)$ & none & 2 & $0^{\mathrm{d}}$ & $36^{\mathrm{d}}$ \\
6 & $\mathbf{1 c}\left(p-\mathrm{ClC}_{6} \mathrm{H}_{4}\right)$ & acetic acid $^{\mathrm{c}}$ & 2 & $33^{\mathrm{d}}$ & $47^{\mathrm{d}}$ \\
\hline
\end{tabular}

a Conditions: 1a-c (0.14 mmol), $2(0.42 \mathrm{mmol})$, phenanthrene (0.07 mmol), $\mathrm{CH}_{3} \mathrm{CN}(8 \mathrm{~mL}), 300 \mathrm{~W}$ high-pressure mercury lamp, Pyrex, r.t. ${ }^{b}$ Determined by using GC. ${ }^{c} 1 \mathrm{~mL} .{ }^{d}$ Determined by using ${ }^{1} \mathrm{H}-\mathrm{NMR}$.

Structures of photoproducts $3 \mathbf{a}-\mathbf{c}$ and $4 \mathbf{a}-\mathbf{c}$ were determined by using spectroscopic methods. In ${ }^{1} \mathrm{H}-\mathrm{NMR}$ spectra of $\mathrm{CDCl}_{3}$ solutions of $\mathbf{3 a}$ and $4 \mathbf{a}$ (Figure 1), the chemical shifts of resonances for protons that are bonded to the asymmetric carbons, i.e., $\mathrm{H}_{\mathrm{b}}$ in $3 \mathbf{a}$ and $\mathrm{H}_{\mathrm{h}}$ in $4 \mathrm{a}$, were $2.97(\mathrm{qd})$ and 3.02 (qt) ppm, respectively. Authentic samples of the photoproducts were prepared by hydrogenation of $1 \mathrm{a}$ using $\mathrm{Pd} / \mathrm{C}$ to form $4 \mathbf{a}$ and ensuing allylation of $4 \mathbf{a}$ using allyl chloride to form $3 \mathbf{a}$ (Scheme 3 ). The spectral data for the synthesized compounds were identical to those of photoproduced $3 \mathbf{a}$ and $\mathbf{4 a}$. 
(a)

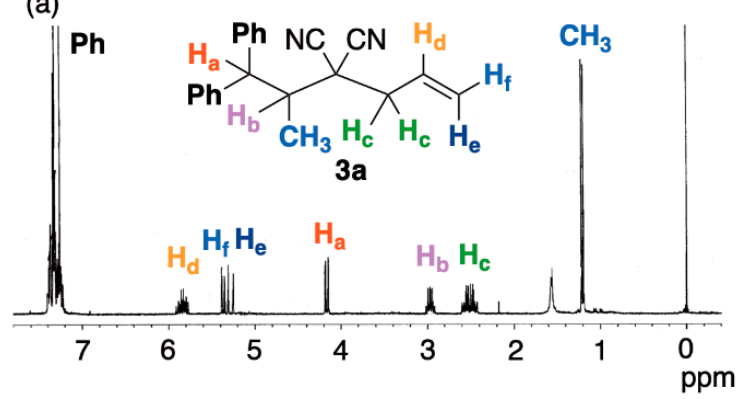

(b)

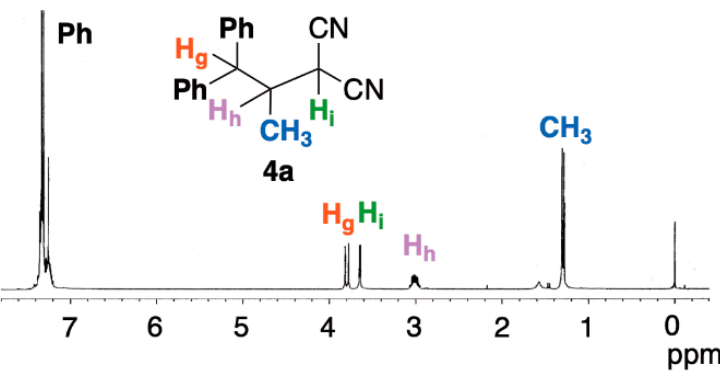

Figure 1. $300 \mathrm{MHz}{ }^{1} \mathrm{H}-\mathrm{NMR}$ spectra of $\mathbf{3} \mathbf{a}$ and $\mathbf{4 a}$ in $\mathrm{CDCl}_{3}$.<smiles>C=CCC(C)(C#N)C(C(c1ccccc1)c1ccccc1)C(C)(C#N)c1ccccc1</smiles>

Scheme 3. Synthesis of authentic samples of 3a and $\mathbf{4 a}$.

In order to explore the enantioselectivities of these photoreactions, samples of $\mathbf{3 a}$ and $4 \mathbf{a}$ were subjected to HPLC using a chiral stationary phase with the effluents being monitored by using UV and CD detectors (Figure 2a-d). The results showed that two peaks in the HPLC trace for the enantiomers of 3a and 4a were completely resolved. Unfortunately, HPLC conditions could not be found for resolution of the enantiomers of $3 b$ and $\mathbf{4 b}$. Moreover, the enantiomers of $3 c$ and $4 c$ can be separated by using GC with a chiral capillary column (Figure 2e).

(a) 3a, chiral HPLC, UV detector

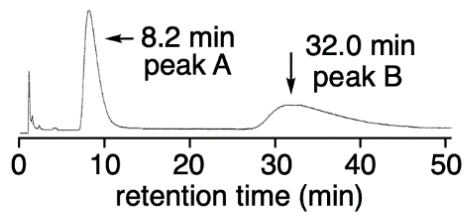

(b) 3a, chiral HPLC, CD detector

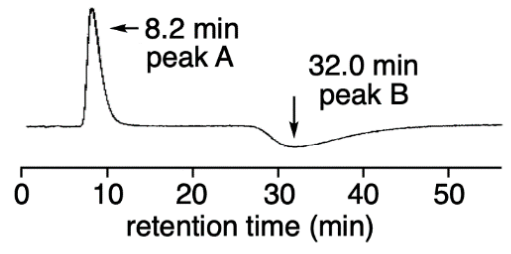

(c) 4a, chiral HPLC, UV detector

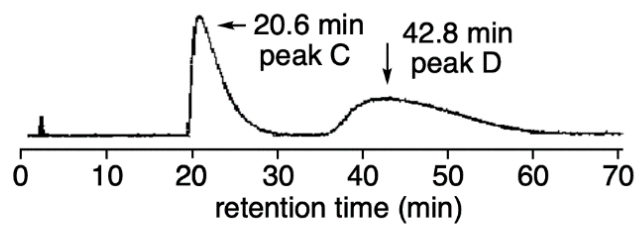

(d) 4a, chiral HPLC, CD detector

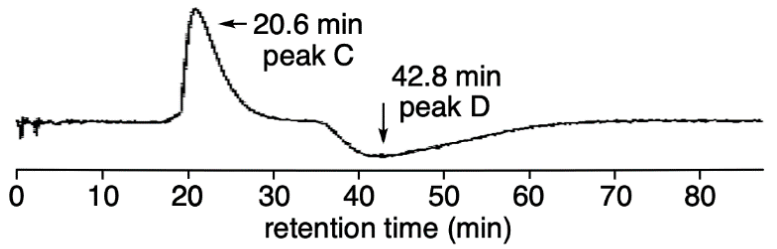

(e) 3c and 4c, chiral GC, MS detector

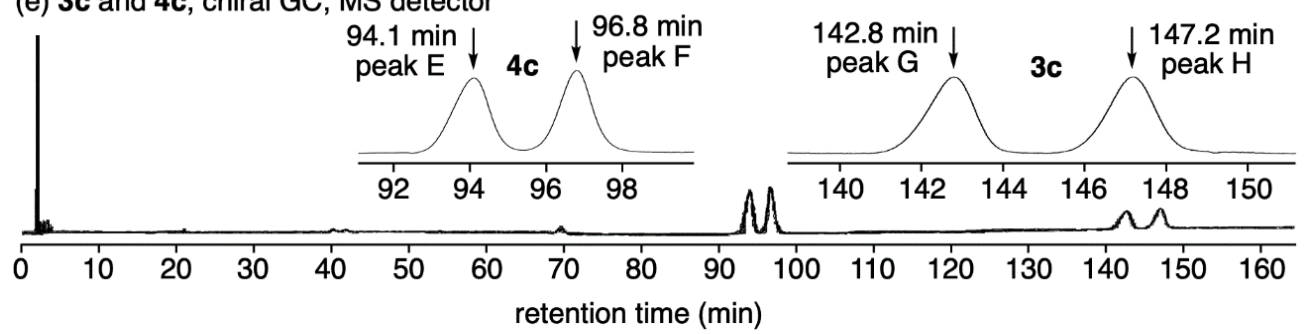

Figure 2. Resolution of the enantiomers of $(\mathbf{a}, \mathbf{b})$ 3a by using chiral HPLC with UV and CD detectors both at $270 \mathrm{~nm},(\mathbf{c}, \mathbf{d}) 4 \mathbf{a}$ by chiral HPLC with UV and CD detectors both at $270 \mathrm{~nm}$, and (e) $3 \mathrm{c}$ and $4 \mathrm{c}$ by chiral GC with a MS detector. 
In order to prove that these separation techniques led to the individual enantiomers, the effluents of peaks A-D in Figure 2a-d were collected, concentrated in vacuo and the residues in ethanol were subjected to UV-vis absorption and CD spectroscopic analysis (Figures 3 and 4). The UV-vis absorption spectra of substances in effluents corresponding to peaks $A$ and $C$ were identical to those from peaks $\mathrm{B}$ and $\mathrm{D}$, respectively. In addition, ${ }^{1} \mathrm{H}-\mathrm{NMR}$ and mass spectra of the respective substances in peaks $A$ and $C$ were also identical to those in peaks $B$ and D, respectively. Moreover, CD spectral traces of substances comprising peaks $\mathrm{A}$ and $\mathrm{B}$, and peaks $\mathrm{C}$ and $\mathrm{D}$, respectively, were mirror images relative to the horizontal base line. The combined results indicated that the enantiomers of these substances can be resolved by using chromatographic methods.

(a) peak $A$

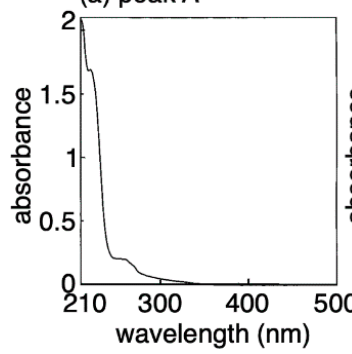

(b) peak B

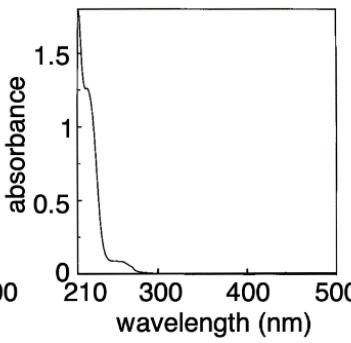

(c) peak C

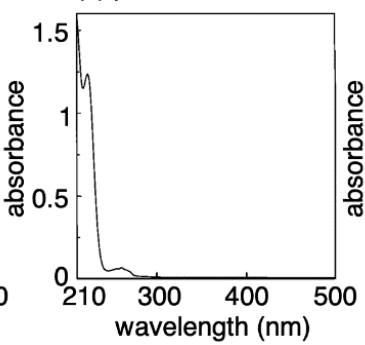

(d) peak D

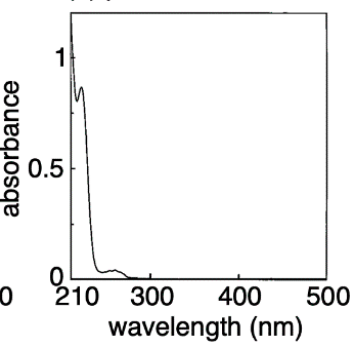

Figure 3. UV-vis absorption spectra of ethanol solutions of substances from (a) peak A, (b) peak B, (c) peak $\mathrm{C}$, and $(\mathbf{d})$ peak D.

(a)

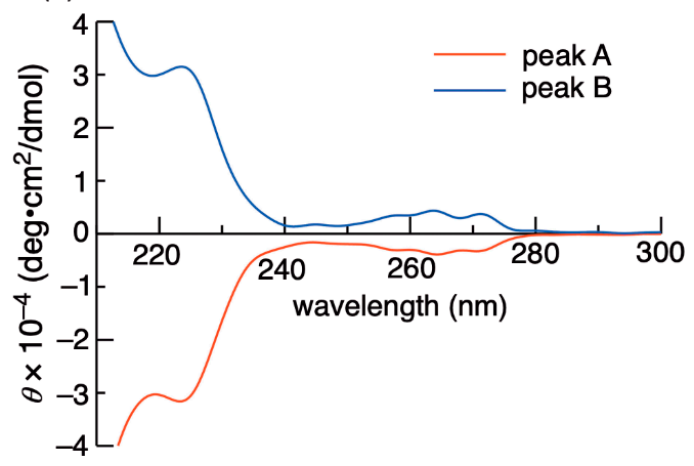

(b)

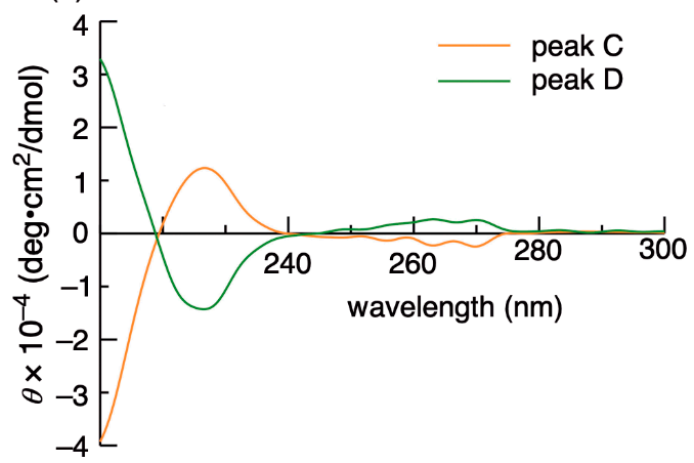

Figure 4. Circular dichromism (CD) spectra of ethanol solutions of substances from (a) peaks A and B, (b) peaks $C$ and D.

To assess the potential of introducing enantioselectivity into the photoreactions described above, irradiations were carried out on solutions of $\mathbf{1 a}-\mathbf{c}$ and allyltrimethylsilane (2) containing chiral carboxylic acids. The yields and percent enantiomeric excesses (\%ee) of products formed in these processes are listed in Table 2. The \%ee in each case was calculated using the ratio of areas under the chiral HPLC or GC peaks corresponding to the enantiomers as \%ee when acetic acid was used becoming zero. A positive \%ee value corresponds to a situation in which the major isomer is the second peak, while a negative value shows that the major isomer is the first peak. The absolute structures could not be decided. The data arising from photoreactions in the absence or presence of achiral acetic acid are also included in Table 2 for comparison purposes.

Use of 1 equiv of $(R)$-mandelic acid in photoreaction of 1a with 2 led to formation of $3 \mathbf{a}$ and $4 \mathbf{a}$ with respective +1.5 and $+4.1 \%$ ee values (entry 3 ). A reversal in major enantiomers of the products arose from the reaction of $\mathbf{1 a}$ with $\mathbf{2}$ conducted in the presence of $(S)$-mandelic acid (entry 4), which supports the reaction proceeding in an enantioselective manner. Also, when L-lactic acid was used in this photoreaction, the major enantiomers were the reverse of those formed in reactions in the presence of (S)-mandelic acid (entry 5). The use of $C_{2}$ symmetric dibenzoyl L-tartaric acid did not promote an increase of \%ee of either product (entry 6). The photoreaction of $\mathbf{1} \mathbf{b}$ with $\mathbf{2}$ also 
occurred when $(R)$ - and $(S)$-mandelic acids were used, however the \%ee of either product could not be determined (entries 9 and 10). Like in the case of 1a, photoreaction of $1 \mathrm{c}$ produced products $3 \mathbf{c}$ and $4 \mathbf{c}$ in which the major enantiomers were reversed when $(R)$ - and $(S)$-mandelic acids were utilized (entries 13 and 14). Moreover, the results showed that the \%ee improved up to 3.5 when (S)-2-(6-methoxy-2-naphthyl)propionic acid was used as a chiral acid (entry 15).

Table 2. Enantioselective photoallylations and photoreductions of $1 \mathbf{a}-\mathbf{c}^{\mathrm{a}}$.

\begin{tabular}{|c|c|c|c|c|c|c|}
\hline \multirow{2}{*}{ Entry } & \multirow{2}{*}{ Substrate } & \multirow{2}{*}{\multicolumn{2}{|c|}{ Additive }} & \multirow{2}{*}{$\begin{array}{l}\text { Irradiation } \\
\text { Time/h }\end{array}$} & \multicolumn{2}{|c|}{ Yields/\% (ee/\%) } \\
\hline & & & & & 3 & 4 \\
\hline 1 & $1 \mathrm{a}(\mathrm{Ar}=\mathrm{Ph})$ & & none & 4 & $0^{\mathrm{b}}$ & $53^{b}$ \\
\hline 2 & $1 \mathbf{a}(\mathrm{Ar}=\mathrm{Ph})$ & $\mathrm{MeCOOH}$ & acetic acid ${ }^{\mathrm{c}}$ & 4 & $34^{b}$ & $31^{b}$ \\
\hline 3 & $\mathbf{1 a}(\mathrm{Ar}=\mathrm{Ph})$ & $\stackrel{\mathrm{Ph}}{\mathrm{I}}_{\mathrm{COOH}}$ & $(R)$-mandelic acid & 4 & $34^{\mathrm{b}}\left(+1.5^{\mathrm{d}, \mathrm{e}}\right)$ & $27^{\mathrm{b}}\left(+4.1^{\mathrm{d}, \mathrm{e}}\right)$ \\
\hline 4 & $\mathbf{1 a}(\mathrm{Ar}=\mathrm{Ph})$ & $\mathrm{Ph} \stackrel{\stackrel{\mathrm{OH}}{\dot{\Lambda}}}{\mathrm{COOH}}$ & (S)-mandelic acid & 4 & $22^{b}\left(-3.4^{d, f}\right)$ & $26^{\mathrm{b}}\left(-4.8^{\mathrm{d}, \mathrm{f}}\right)$ \\
\hline 5 & 1a $(\mathrm{Ar}=\mathrm{Ph})$ & & L-lactic acid & 4 & $28^{\mathrm{b}}\left(+0.6^{\mathrm{d}, \mathrm{e}}\right)$ & $39^{b}\left(+3.2^{d, e}\right)$ \\
\hline 6 & $\mathbf{1 a}(\mathrm{Ar}=\mathrm{Ph})$ & $\mathrm{HOOC}_{\mathrm{COOH}}^{\mathrm{OCOPh}}$ & dibenzoyl L-tartaric acid & 4 & $31^{b}\left(-2.0^{d, f}\right)$ & $16^{\mathrm{b}}\left(-3.6^{\mathrm{d}, \mathrm{f}}\right)$ \\
\hline 7 & $\mathbf{1 b}\left(\mathrm{Ar}=p-\mathrm{MeOC}_{6} \mathrm{H}_{4}\right)$ & & none & 24 & $0 \mathrm{~g}$ & $44^{g}$ \\
\hline 8 & $\mathbf{1 b}\left(\mathrm{Ar}=p-\mathrm{MeOC}_{6} \mathrm{H}_{4}\right)$ & $\mathrm{MeCOOH}$ & 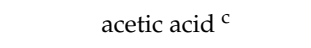 & 24 & $20 \mathrm{~g}$ & $46^{\mathrm{g}}$ \\
\hline 10 & $\mathbf{1 b}\left(\mathrm{Ar}=p-\mathrm{MeOC}_{6} \mathrm{H}_{4}\right)$ & $\mathrm{Ph} \stackrel{\mathrm{OH}}{\overbrace{\mathrm{H}}} \mathrm{COOH}$ & (S)-mandelic acid & 24 & $13^{g}\left(\right.$ nd $\left.^{h}\right)$ & $48^{\mathrm{g}}\left(\right.$ nd $\left.^{\mathrm{h}}\right)$ \\
\hline 11 & 1c $\left(p-\mathrm{ClC}_{6} \mathrm{H}_{4}\right)$ & & none & 2 & $0^{g}$ & $36^{g}$ \\
\hline 12 & 1c $\left(p-\mathrm{ClC}_{6} \mathrm{H}_{4}\right)$ & $\mathrm{MeCOOH}$ & acetic acid ${ }^{\mathrm{c}}$ & 2 & $33^{g}$ & $47^{g}$ \\
\hline 13 & 1c $\left(p-\mathrm{ClC}_{6} \mathrm{H}_{4}\right)$ & $\mathrm{Ph}_{\mathrm{COOH}}^{1}$ & $(R)$-mandelic acid & 2 & $27^{g}\left(+2.0^{i, j}\right)$ & $55^{\mathrm{g}}\left(+2.0^{\mathrm{i}, \mathrm{j}}\right)$ \\
\hline 14 & 1c $\left(p-\mathrm{ClC}_{6} \mathrm{H}_{4}\right)$ & $\mathrm{Ph} \stackrel{\mathrm{OH}}{\stackrel{\mathrm{OH}}{\dot{\Lambda}}} \mathrm{COOH}$ & $(S)$-mandelic acid & 2 & $24^{g}\left(-2.6^{\mathrm{i}, \mathrm{k}}\right)$ & $61^{g}\left(-0.6^{\mathrm{i}, \mathrm{k}}\right)$ \\
\hline 15 & 1c $\left(p-\mathrm{ClC}_{6} \mathrm{H}_{4}\right)$ & $\mathrm{MeO}^{\text {If }}$ & $\begin{array}{c}\text { (S)-2-(6-methoxy-2- } \\
\text { naphthyl)propionic acid }\end{array}$ & 2 & $0 \mathrm{~g}$ & $68^{\mathrm{g}}\left(-3.5^{\mathrm{i}, \mathrm{k}}\right)$ \\
\hline
\end{tabular}

a Conditions: 1a-c $(0.14 \mathrm{mmol}), 2(0.42 \mathrm{mmol})$, phenanthrene $(0.07 \mathrm{mmol}), \mathrm{CH}_{3} \mathrm{CN}(8 \mathrm{~mL})$, additive $(0.14 \mathrm{mmol}), 300$ W high-pressure mercury lamp, Pyrex, r.t. ${ }^{b}$ Determined by using GC. ${ }^{c} 1 \mathrm{~mL} .{ }^{\mathrm{d}}$ Determined by using chiral HPLC. ${ }^{\mathrm{e}}$ Major isomer corresponds to the second peak in the HPLC chart. ${ }^{\mathrm{f}}$ Major isomer corresponds to the first peak in the HPLC chart. ${ }^{\mathrm{g}}$ Determined by using ${ }^{1} \mathrm{H}-\mathrm{NMR} .{ }^{\mathrm{h}}$ Ee could not be determined. ${ }^{\mathrm{i}}$ Determined by using chiral GC. ${ }^{j}$ Major isomer corresponds to the second peak in the GC chart. ${ }^{k}$ Major isomer corresponds to the first peak in the GC chart.

Each photoreaction described above takes place through a process termed photoredox sensitization by phenanthrene (Phen) (Scheme 4) [22-27]. In the pathway, the excited singlet state of Phen, generated by light absorption, transfers one electron (SET (single electron transfer)) to the electron-deficient alkene 1 to form the phenanthrene radical cation $\left(\mathrm{Phen}^{\bullet+}\right.$ ) and the alkene radical anion $\mathbf{1}^{\bullet-}$. The subsequent SET from allyltrimethylsilane (2) to Phen ${ }^{\bullet+}$ generates recovered Phen and the radical cation $\mathbf{2}^{\bullet+}$, which undergoes nucleophile-assisted Si-C bond cleavage [28-30] to form the allyl radical. Also, radical anion $\mathbf{1}^{\mathbf{-}}$ is protonated by the carboxylic acid to produce radical 5 , which upon coupling with the allyl radical generates the allylation product 3 . In a competitive pathway, radical 5 undergoes hydrogen abstraction or one-electron reduction followed by protonation or disproportionation to form reduction product 4 [23]. The inefficiency of the photoreaction of the MeO-substituted substrate $\mathbf{1 b}$ and high efficiency of the reaction of $\mathrm{Cl}$-substituted reactant $1 \mathrm{c}$ are likely consequences of the stabilities of the corresponding radical anions $\mathbf{1} \mathbf{b}^{\bullet-}$ and $\mathbf{1} \mathbf{c}^{\bullet-}$ which governs their rates of formation by SET from relative to unproductive decay of the excited singlet state of Phen. 
Based on the results of molecular orbital calculations with related compounds, it is estimated that the radical contribution to radical anion $\mathbf{1}^{\mathbf{}}$ is large at the dicyano substituted carbon $(\alpha)$ and that negative charge density is large at the dialkyl substituted carbon $(\beta)[23,24,26,27]$. In accord with this conclusion, the photoreaction of $\mathbf{1 a}$ with $\mathbf{2}$ using $\mathrm{CH}_{3} \mathrm{COOD}$ as the additive produced mainly mono-deuteriated forms of $\mathbf{3} \mathbf{a}$ and $\mathbf{4} \mathbf{a}$ in which deuterium is present at the stereogenic carbons marked with * in Scheme 4. Therefore, enantioselectivity is governed at the step where protonation of the radical anion takes place.

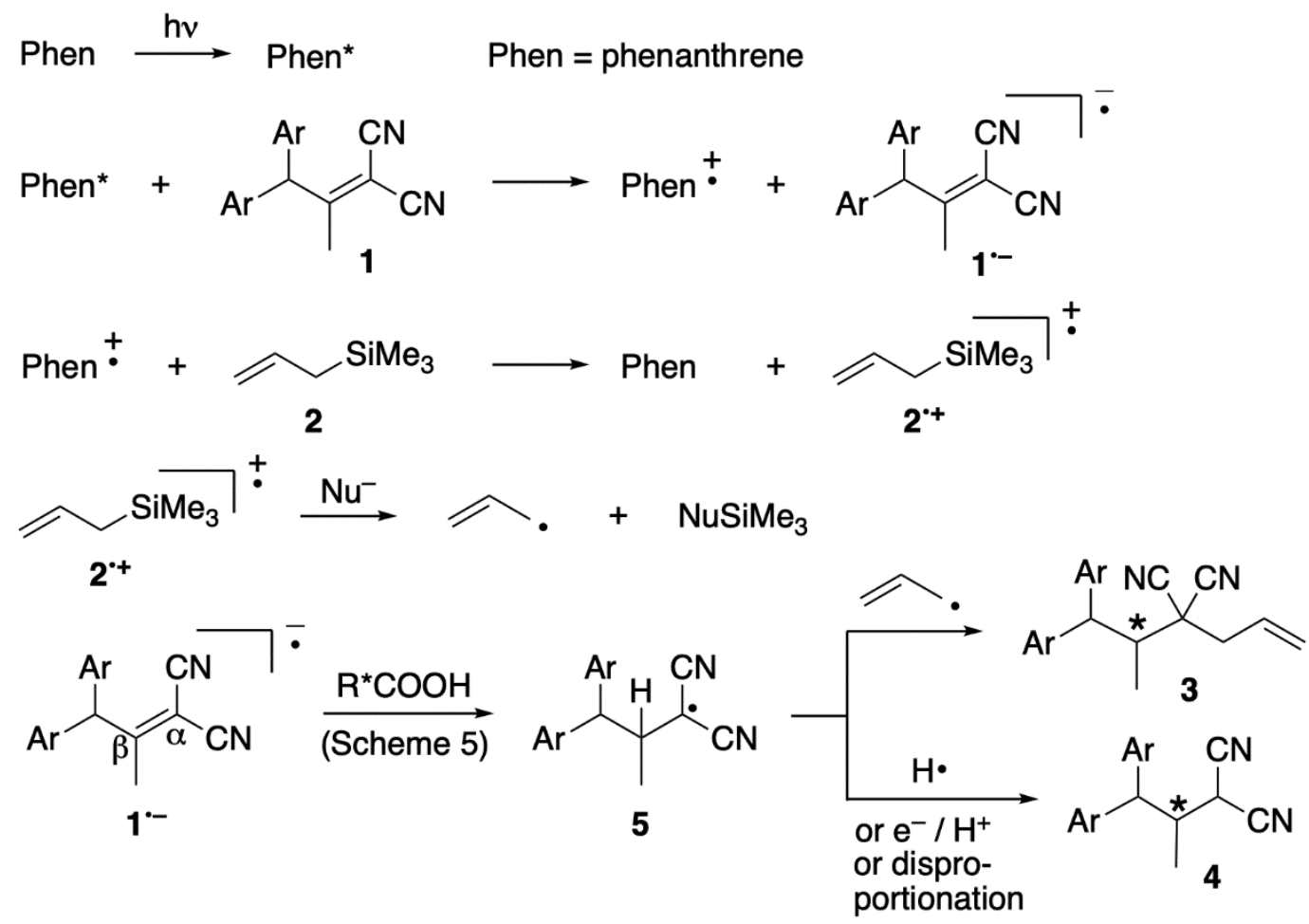

Scheme 4. Mechanism for photoallylation and photoreduction of $\mathbf{1}$.

The stereochemistry of protonation of the radical anion $\mathbf{1}^{\mathbf{}-}$ can be discussed using a Felkin-Anh model (Scheme 5) [31-33]. Specifically, in reaction of 1a in the presence of (S)-mandelic acid, proton transfer to the $R e$ face of $1 \mathrm{a}^{\bullet-}$ should be preferred in a complex in which a $\pi-\pi$ stabilizing interaction occurs between the phenyl groups and the $\mathrm{OH}$ group of the acid is located in a sterically less hindered position. Proton transfer to the $R e$ face of $\mathbf{1 a}$ leads to the eventual formation of (S)-3a and (S)-4a. On the other hand, in the reaction of $\mathbf{1 a}$ in the presence of L-lactic acid, an $\mathrm{OH}-\pi$ interaction between the $\mathrm{OH}$ group of the acid and the phenyl group of $1 \mathrm{a}^{\bullet-}$ takes place to form a complex in which proton transfer from the carboxylic acid group occurs preferentially to the $S i$ face to minimize steric repulsion of methyl group. This process then gives rise to formation of $(R)-\mathbf{3 a}$ and $(R)-\mathbf{4 a}$. In photoreaction of $\mathbf{1 c}$ in the presence of (S)-2-(6-methoxy-2-naphthyl)propionic acid, the main enantiomers produced were the same as those generated in reaction of $\mathbf{1} \mathbf{c}$ in the presence of (S)-mandelic acid, and \%ee increased. This outcome might be a consequence of a strong $\pi-\pi$ interaction between the chlorophenyl and the methoxynaphthyl groups. 


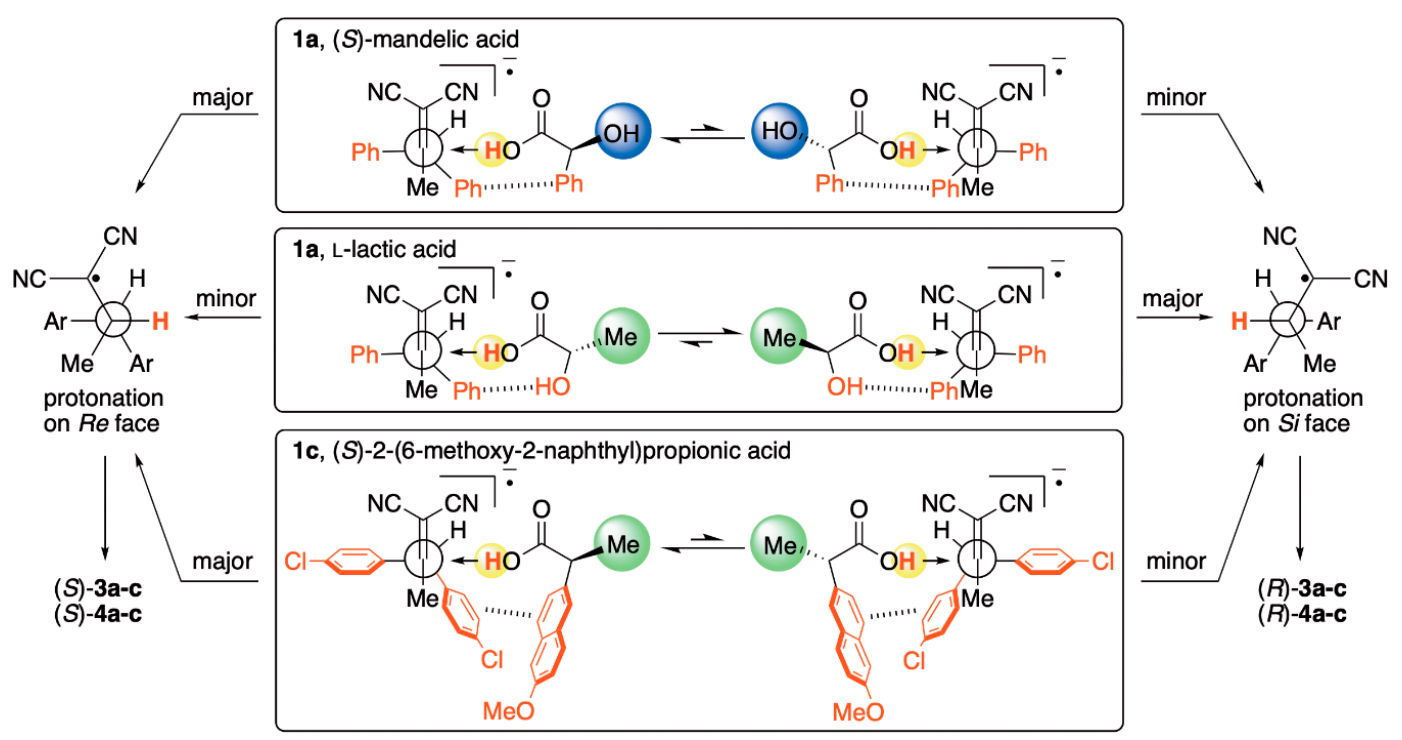

Scheme 5. Plausible explanation for the enantioselectivity.

\section{Experimental Section}

\subsection{Materials and Equipments}

THF was distilled from $\mathrm{CaH}_{2}$ and then from $\mathrm{Na}$ /benzophenone. $\mathrm{CH}_{3} \mathrm{CN}$ was distilled from $\mathrm{P}_{2} \mathrm{O}_{5}$ then from $\mathrm{Ca}(\mathrm{OH})_{2}$. Hexane and 2-propanol were distilled without using a drying agent. Allyltrimethylsilane (2) was prepared using a reported procedure [27]. Activated alumina was dried at $200{ }^{\circ} \mathrm{C}$ for $2 \mathrm{~h}$ before use. Most other chemical substances were used after purification by distillation or recrystallization.

Column chromatography was conducted by using Wakogel C-70 230 (Fujifilm Wako Pure Chemical Corporation, Osaka, Japan). Thin-layer chromatography was performed by using Merck Kiesel gel $60 \mathrm{~F}_{254}$ plates (Merck KGaA, Darmstadt, Germany). HPLC separations (achiral) were performed on a recycling preparative HPLC equipped with Jasco PU-987 pump, UV-970 UV detector, and a Chemcosorb I-5Si column (Chemco Plus Scientific Co., Ltd., Osaka, Japan) using hexane-AcOEt or hexane-2-propanol as an eluent, or a recycling preparative HPLC equipped with Jasco PU-2086 pump, RI-2031 differential refractometer (Jasco Corporation, Tokyo, Japan), and Megapak GEL 201F columns (GPC) using $\mathrm{CHCl}_{3}$ as an eluent (Jasco Corporation, Tokyo, Japan).

${ }^{1} \mathrm{H}$ and ${ }^{13} \mathrm{C}-\mathrm{NMR}$ spectra were recorded using a Varian MERCURY-300 (300 MHz and $75 \mathrm{MHz}$, respectively, (Varian Inc., Palo Alto, CA, USA) spectrometer with $\mathrm{Me}_{4} \mathrm{Si}$ as an internal standard. Mass spectra (EI, achiral) were recorded on a SHIMADZU GCMS-QP5050 (Shimadzu Corporation, Kyoto, Japan) operating in the electron impact mode (70 eV) equipped with GC-17A and DB-5MS column (J\&W Scientific Inc., Serial: 8696181, Folsom, CA, USA). UV-vis spectra were recorded using a Jasco V-530 spectrophotometer (Jasco Corporation, Tokyo, Japan).

\subsection{Preparation of $\mathbf{1 a}$}

A mixture of 1,1-diphenylacetone $(1.051 \mathrm{~g}, 5.0 \mathrm{mmol})$, malononitrile $(0.330 \mathrm{~g}, 5.0 \mathrm{mmol})$ and activated alumina $(1.5 \mathrm{~g})$ was stirred at $60{ }^{\circ} \mathrm{C}$ for $1 \mathrm{~h} \mathrm{[34]}$. The solids were removed by filtration. Concentration of the filtrate gave a residue that was subjected to silica gel column chromatography followed by recrystallization from hexane to give 2-(1,1-diphenylpropan-2-ylidene)malononitrile (1a, white solid, $0.531 \mathrm{~g}, 2.06 \mathrm{mmol}, 41 \%$ yield). Lit [35]. 


\subsection{Preparation of $\mathbf{1 b}$}

A THF ( $50 \mathrm{~mL})$ solution of 4-bromoanisole $(17.53 \mathrm{~mL}, 140.0 \mathrm{mmol})$ was added dropwise to stirred Mg turnings ( $3.889 \mathrm{~g}, 160.0 \mathrm{mmol})$. A small amount of $\mathrm{I}_{2}$ was added to facilitate the reaction. A THF $(20 \mathrm{~mL})$ solution of ethyl L-lactate $(4.587 \mathrm{~mL}, 40.0 \mathrm{mmol})$ was added dropwise to the solution, and the resulting mixture was stirred at reflux, cooled, and extracted with $\mathrm{Et}_{2} \mathrm{O}$ and $\mathrm{NH}_{4} \mathrm{Cl}$ aq [36]. The organic layer was dried over $\mathrm{Na}_{2} \mathrm{SO}_{4}$, filtered, and concentrated in vacuo, giving a residue that was subjected to silica gel column chromatography to give 1,1-bis(4-methoxyphenyl)propane-1,2-diol (5.76 g, $20.0 \mathrm{mmol}$, $50 \%$ yield, including inpurity).

$25 \% \mathrm{H}_{2} \mathrm{SO}_{4}$ aq (15 mL) was added to stirred 1,1-bis(4-methoxyphenyl)propane-1,2-diol (5.76 g, $20.0 \mathrm{mmol}$, including inpurity), and the resulting solution was stirred at reflux for $3.5 \mathrm{~h}$, cooled, neutralized with $\mathrm{Na}_{2} \mathrm{CO}_{3}$ and extracted with $\mathrm{Et}_{2} \mathrm{O}$ [36]. The organic layer was dried over $\mathrm{Na}_{2} \mathrm{SO}_{4}$, filtered, and concentrated in vacuo, giving a residue that was subjected to silica gel column chromatography to give 1,1-bis(4-methoxyphenyl)propan-2-one (1.047 g, $3.87 \mathrm{mmol}, 19 \%$ yield).

A mixture of 1,1-bis(4-methoxyphenyl)propan-2-one (1.047 g, $3.87 \mathrm{mmol})$, malononitrile ( $0.384 \mathrm{~g}$, $5.82 \mathrm{mmol})$ and activated alumina $(3.0 \mathrm{~g})$ was stirred at $90{ }^{\circ} \mathrm{C}$ for $1.5 \mathrm{~h}$ [34]. The solids were removed by filtration. Concentration of the filtrate gave a residue that was subjected to HPLC to give 2-[1,1-bis(4-methoxyphenyl)propan-2-ylidene]malononitrile (1b, $0.728 \mathrm{~g}, 2.29 \mathrm{mmol}, 59 \%$ yield). ${ }^{1} \mathrm{H}-\mathrm{NMR}\left(300 \mathrm{MHz}, \mathrm{CDCl}_{3}\right) \delta 2.21(\mathrm{~s}, 3 \mathrm{H}), 3.82(\mathrm{~s}, 6 \mathrm{H}), 5.59(\mathrm{~s}, 1 \mathrm{H}), 6.89(\mathrm{~d}, J=8.6 \mathrm{~Hz}, 4 \mathrm{H}), 7.05(\mathrm{~d}$, $J=8.6 \mathrm{~Hz}, 4 \mathrm{H}) \mathrm{ppm}$.

\subsection{Preparation of $1 c$}

A THF (12 mL) solution of 4-bromochlorobenzene $(6.647 \mathrm{~g}, 34.7 \mathrm{mmol})$ was added dropwise to stirred $\mathrm{Mg}$ turnings $(0.729 \mathrm{~g}, 30.0 \mathrm{mmol})$. A small amount of $\mathrm{I}_{2}$ was added to facilitate the reaction. A THF $(5 \mathrm{~mL})$ solution of ethyl L-lactate $(1.247 \mathrm{~mL}, 10.9 \mathrm{mmol})$ was added dropwise to the solution, and the resulting solution was stirred at reflux, cooled, and extracted with $\mathrm{Et}_{2} \mathrm{O}$ and $\mathrm{NH}_{4} \mathrm{Cl}$ aq [36]. The organic layer was dried over $\mathrm{Na}_{2} \mathrm{SO}_{4}$, filtered, and concentrated in vacuo, giving a residue that was subjected to silica gel column chromatography to give 1,1-bis(4-chlorophenyl)propane-1,2-diol (4.023 g, including inpurity).

To stirred 1,1-bis(4-chlorophenyl)propane-1,2-diol (4.023 g, including inpurity) was added 25\% $\mathrm{H}_{2} \mathrm{SO}_{4}$ aq $(12 \mathrm{~mL})$, and the resulting solution was stirred at reflux for $3.5 \mathrm{~h}$, cooled, neutralized with $\mathrm{Na}_{2} \mathrm{CO}_{3}$ and extracted with $\mathrm{Et}_{2} \mathrm{O}$ [36]. The organic layer was dried over $\mathrm{Na}_{2} \mathrm{SO}_{4}$, filtered, and concentrated in vacuo, giving a residue that was subjected to silica gel column chromatography to give 1,1-bis(4-chlorophenyl)propan-2-one $\left(0.934 \mathrm{~g}, 3.36 \mathrm{mmol}, 31 \%\right.$ yield (two steps)). ${ }^{1} \mathrm{H}-\mathrm{NMR}$ $\left(300 \mathrm{MHz}, \mathrm{CDCl}_{3}\right) \delta 2.24(\mathrm{~s}, 3 \mathrm{H}), 5.05(\mathrm{~s}, 1 \mathrm{H}), 7.11-7.32(\mathrm{~m}, 8 \mathrm{H}) \mathrm{ppm}$.

A mixture of 1,1-bis(4-chlorophenyl)propan-2-one $(0.934 \mathrm{~g}, 3.36 \mathrm{mmol})$, malononitrile $(0.444 \mathrm{~g}$,

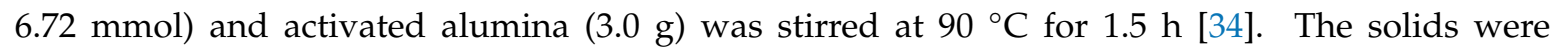
removed by filtration. Concentration of the filtrate gave a residue that was subjected to HPLC to give 2-[1,1-bis(4-chlorophenyl)propan-2-ylidene]malononitrile (1c, $0.602 \mathrm{~g}, 1.84 \mathrm{mmol}, 55 \%$ yield). ${ }^{1} \mathrm{H}-\mathrm{NMR}\left(300 \mathrm{MHz}, \mathrm{CDCl}_{3}\right) \delta 2.21(\mathrm{~s}, 3 \mathrm{H}), 5.62(\mathrm{~s}, 1 \mathrm{H}), 7.05(\mathrm{~d}, J=8.4 \mathrm{~Hz}, 4 \mathrm{H}), 7.37(\mathrm{~d}, J=8.4 \mathrm{~Hz}, 4 \mathrm{H})$ ppm; ${ }^{13} \mathrm{C}-\mathrm{NMR}\left(75 \mathrm{MHz}, \mathrm{CDCl}_{3}\right) \delta 21.33,55.87,88.80,111.37,111.49,129.47,129.94,134.47,135.75$, 179.56 ppm; MS (EI) m/z (relative intensity, \%) = 114 (52), 139 (89), 165 (59), 291 (100), $326\left(62, \mathrm{M}^{+}\right)$.

\subsection{General Procedure for Photoreactions}

$\mathrm{CH}_{3} \mathrm{CN}$ (8 mL) solutions of a 3,3-diaryl-1,1-dicyano-2-methylprop-2-ene (1a-c, $\left.0.14 \mathrm{mmol}\right)$, allyltrimethylsilane $(2,0.42 \mathrm{mmol})$, phenanthrene $(0.07 \mathrm{mmol})$, and $\mathrm{CH}_{3} \mathrm{COOH}(1 \mathrm{~mL})$ or a chiral carboxylic acid $(0.14 \mathrm{mmol})$ in Pyrex vessels were degassed by argon bubbling for $5 \mathrm{~min}$ and then the vessels were sealed. The solutions were irradiated by using a $300 \mathrm{~W}$ high pressure mercury lamp (Eikosha, EHB-W-300 or PIH-300) for 2-24 h at room temperature, maintained by using circulated cooling water. The photolysates were extracted with $\mathrm{Et}_{2} \mathrm{O}$. The organic layer was washed with $\mathrm{H}_{2} \mathrm{O}$, 
dried over $\mathrm{Na}_{2} \mathrm{SO}_{4}$, filtered, and concentrated in vacuo, giving a residue that was subjected to HPLC to give $3 \mathbf{a}-\mathbf{c}$ and $4 \mathbf{a}-\mathbf{c}$.

2-Allyl-2-(1,1-diphenylpropan-2-yl)malononitrile (3a): ${ }^{1} \mathrm{H}-\mathrm{NMR}\left(300 \mathrm{MHz}, \mathrm{CDCl}_{3}\right) \delta 1.20$ (d, $J=6.8 \mathrm{~Hz}, 3 \mathrm{H}), 2.42-2.59(\mathrm{~m}, 2 \mathrm{H}), 2.91-3.02(\mathrm{~m}, 1 \mathrm{H}), 4.16(\mathrm{~d}, J=9.3 \mathrm{~Hz}, 1 \mathrm{H}), 5.28(\mathrm{~d}, J=17.6 \mathrm{~Hz}, 1 \mathrm{H})$, $5.37(\mathrm{~d}, J=9.6 \mathrm{~Hz}, 1 \mathrm{H}), 5.76-5.92(\mathrm{~m}, 1 \mathrm{H}), 7.21-7.40(\mathrm{~m}, 10 \mathrm{H}) \mathrm{ppm}$; MS (EI) $\mathrm{m} / z=41,65,77,91,102,115$, $128,151,165,167,193,300\left(\mathrm{M}^{+}\right)$.

2-Allyl-2-[1,1-bis(4-methoxyphenyl)propan-2-yl]malononitrile (3b): ${ }^{1} \mathrm{H}-\mathrm{NMR}\left(300 \mathrm{MHz}, \mathrm{CDCl}_{3}\right) \delta$ $1.18(\mathrm{~d}, J=6.7 \mathrm{~Hz}, 3 \mathrm{H}), 2.44-2.60(\mathrm{~m}, 2 \mathrm{H}), 2.80-2.91(\mathrm{~m}, 1 \mathrm{H}), 3.76(\mathrm{~s}, 3 \mathrm{H}), 3.78(\mathrm{~s}, 3 \mathrm{H}), 4.08(\mathrm{~d}, J=9.2 \mathrm{~Hz}$, $1 \mathrm{H}), 5.29(\mathrm{~d}, J=16.9 \mathrm{~Hz}, 1 \mathrm{H}), 5.36(\mathrm{~d}, J=10.0 \mathrm{~Hz}, 1 \mathrm{H}), 5.77-5.91(\mathrm{~m}, 1 \mathrm{H}), 6.81-6.87(\mathrm{~m}, 4 \mathrm{H}), 7.19-7.26$ $(\mathrm{m}, 4 \mathrm{H}) \mathrm{ppm}$.

2-Allyl-2-[1,1-bis(4-chlorophenyl)propan-2-yl]malononitrile (3c): ${ }^{1} \mathrm{H}-\mathrm{NMR}\left(300 \mathrm{MHz}, \mathrm{CDCl}_{3}\right) \delta$ $1.18(\mathrm{~d}, J=6.7 \mathrm{~Hz}, 3 \mathrm{H}), 2.52(\mathrm{dd}, J=13.8,7.5 \mathrm{~Hz}, 1 \mathrm{H}), 2.62(\mathrm{dd}, J=13.9,6.7 \mathrm{~Hz}, 1 \mathrm{H}), 2.88(\mathrm{dq}, J=8.9$, $6.7 \mathrm{~Hz}, 1 \mathrm{H}), 4.15(\mathrm{~d}, J=9.1 \mathrm{~Hz}, 1 \mathrm{H}), 5.31(\mathrm{~d}, J=16.9 \mathrm{~Hz}, 1 \mathrm{H}), 5.40(\mathrm{~d}, J=10.2 \mathrm{~Hz}, 1 \mathrm{H}), 5.76-5.91(\mathrm{~m}, 1 \mathrm{H})$, 7.19-7.36 (m, 8H) ppm; ${ }^{13} \mathrm{C}-\mathrm{NMR}\left(75 \mathrm{MHz}, \mathrm{CDCl}_{3}\right) \delta 15.47,41.40,42.40,42.79,54.31,114.18,123.29$, $128.44,129.24,129.27,129.67,129.93,133.41,133.76,139.09,139.24$ ppm.

2-(1,1-Diphenylpropan-2-yl)malononitrile (4a): ${ }^{1} \mathrm{H}-\mathrm{NMR}\left(300 \mathrm{MHz}, \mathrm{CDCl}_{3}\right) \delta 1.30(\mathrm{~d}, J=6.6 \mathrm{~Hz}$, $3 \mathrm{H}), 2.95-3.06(\mathrm{~m}, 1 \mathrm{H}), 3.64(\mathrm{~d}, J=3.3 \mathrm{~Hz}, 1 \mathrm{H}), 3.80(\mathrm{~d}, J=11.7 \mathrm{~Hz}, 1 \mathrm{H}), 7.21-7.36(\mathrm{~m}, 10 \mathrm{H}) \mathrm{ppm}$; MS (EI) $m / z=51,63,77,83,102,128,151,165,167,193,300\left(\mathrm{M}^{+}\right)$.

2-[1,1-Bis(4-methoxyphenyl)propan-2-yl]malononitrile (4b): ${ }^{1} \mathrm{H}-\mathrm{NMR}\left(300 \mathrm{MHz}, \mathrm{CDCl}_{3}\right) \delta 1.28$ $(\mathrm{d}, J=6.6 \mathrm{~Hz}, 3 \mathrm{H}), 2.82-2.95(\mathrm{~m}, 1 \mathrm{H}), 3.66(\mathrm{~d}, J=3.3 \mathrm{~Hz}, 1 \mathrm{H}), 3.69(\mathrm{~d}, J=11.7 \mathrm{~Hz}, 1 \mathrm{H}), 3.77(\mathrm{~s}, 6 \mathrm{H})$, 6.83-6.89 (m, 4H), 7.18-7.24 (m, 4H) ppm.

2-[1,1-Bis(4-chlorophenyl)propan-2-yl]malononitrile (4c): ${ }^{1} \mathrm{H}-\mathrm{NMR}\left(300 \mathrm{MHz}, \mathrm{CDCl}_{3}\right) \delta 1.29$ $(\mathrm{d}, J=6.6 \mathrm{~Hz}, 3 \mathrm{H}), 2.87-2.98(\mathrm{~m}, 1 \mathrm{H}), 3.60(\mathrm{~d}, J=3.4 \mathrm{~Hz}, 1 \mathrm{H}), 3.78(\mathrm{~d}, J=11.8 \mathrm{~Hz}, 1 \mathrm{H}), 7.18-7.37$ $(\mathrm{m}, 8 \mathrm{H}) \mathrm{ppm}$.

\subsection{Resolution of Enantiomers}

Resolutions of enantiomers of 3a and 4a were performed on a recycling preparative HPLC equipped with Jasco PU-980 pump, Jasco UV-970 and CD-2095 detectors (Jasco Corporation, Tokyo, Japan), Daicel CHIRALCEL OJ (3a) or OJ-H (4a) columns (Daicel Corporation, Osaka, Japan). Eluents were hexane:2-propanol = 7:3 (3a) or 9:1 (4a). [3a] $=0.068 \mathrm{M}$, [4a] $=0.078 \mathrm{M}$. Both 3a and 4a were detected by UV and CD detectors at $270 \mathrm{~nm}$.

Resolutions of enantiomers of $\mathbf{3 c}$ and $\mathbf{4} \mathbf{c}$ were performed by using a SHIMADZU GCMS-QP5050 (Shimadzu Corporation, Kyoto, Japan) operating in the electron impact mode (70 eV) equipped with SUPELCO GAMMA DEXTM 225 column (Sigma-Aldrich Co., LLC, St. Louis, MO, USA). Detector temp $=215{ }^{\circ} \mathrm{C}$, injection temp $=220{ }^{\circ} \mathrm{C}$, inlet pressure $=93.7 \mathrm{kPa}$, flow rate $=1.0 \mathrm{~mL} / \mathrm{min}$, linear velocity $=28.1 \mathrm{~cm} / \mathrm{s}$, split ratio $=50$, carrier gas $=\mathrm{N}_{2}$.

\section{Conclusions}

In summary, we found that photoreactions of prochiral 3,3-diaryl-1,1-dicyano-2-methylprop-1-enes 1a-c with allyltrimethylsilane, carried in the presence of enantiomerically pure chiral carboxylic acids, generates photoallylation and photoreduction products with low but finite levels of enantioselectivity. The percent enantiomeric excesses in the products of the process was highest (4.8\%ee) when (S)-mandelic acid was used. Enantioselectivities in these reactions are a consequence of sterically governed asymmetric proton transfer in intermediate complexes formed by $\pi-\pi$ and $\mathrm{OH}-\pi$ interactions between radical anions of the prochiral alkenes and the chiral carboxylic acids.

Supplementary Materials: The following are available online: ${ }^{1} \mathrm{H}-\mathrm{NMR}$ spectra of $\mathbf{1 b}, \mathbf{1 c}, \mathbf{3 a}, \mathbf{3 b}, \mathbf{3 c}, \mathbf{4 a}$, and $4 \mathbf{c}$, ${ }^{13} \mathrm{C}-\mathrm{NMR}$ spectra of $\mathbf{1 c}$ and $3 \mathrm{c}$.

Author Contributions: Project administration, H.M.; investigation, M.I. and D.O.; supervision, K.M. 
Funding: This study was supported by Grant-in-Aids for Scientific Research on Priority Areas "Reaction Control of Dynamic Complexes (420)" (16033252), Scientific Research (B) (15350026), Scientific Research (C) (17K05777), and Young Scientists (B) (16750039), and the Cooperation for Innovative Technology and Advanced Research in Evolutional Area (CITY AREA) program from the Ministry of Education, Culture, Sports, Science and Technology (MEXT) of Japan.

Acknowledgments: We thank Masahito Oka at Osaka Prefecture University for permission to use circular dichromism (CD) spectrometer.

Conflicts of Interest: The authors declare no conflict of interest.

\section{References}

1. Neunteufel, R.A.; Arnold, D.R. Radical Ions in Photochemistry. I. The 1, 1-Diphenylethylene Cation Radical. J. Am. Chem. Soc. 1973, 95, 4080-4081. [CrossRef]

2. Maroulis, A.J.; Shigemitsu, Y.; Arnold, D.R. Radical Ions in Photochemistry. 5. Photosensitized (Electron Transfer) Cyanation of Olefins. J. Am. Chem. Soc. 1978, 100, 535-541. [CrossRef]

3. Yasuda, M.; Yamashita, T.; Matsumoto, T.; Shima, K.; Pac, C. Synthetic Application of Photochemical Electron Transfer to Direct Amination of Arenes by Ammonia and Primary Amines. J. Org. Chem. 1985, 50, 3667-3669. [CrossRef]

4. Klett, M.W.; Johnson, R.P. Photogeneration of Triphenyl $C_{3}$ Radical Cations: Deprotonation and Nucleophilic Addition as Competitive Pathways. J. Am. Chem. Soc. 1985, 107, 6615-6620. [CrossRef]

5. Kavarnos, G.J.; Turro, N.J. Photosensitization by Reversible Electron Transfer: Theories, Experimental Evidence, and Examples. Chem. Rev. 1986, 86, 401-449. [CrossRef]

6. Yasuda, M.; Yamashita, T.; Shima, K.; Pac, C. Direct Photoamination of Arenes with Ammonia and Primary Amines in the Presence of Electron Acceptors. J. Org. Chem. 1987, 52, 753-759. [CrossRef]

7. Mattay, J. Charge Transfer and Radical Ions in Photochemistry. Angew. Chem. Int. Ed. Engl. 1987, 26, 825-845. [CrossRef]

8. Hasegawa, E.; Xu, W.; Mariano, P.S.; Yoon, U.C.; Kim, J.U. Electron-Transfer-Induced Photoadditions of the Silyl Amine $\mathrm{Et}_{2} \mathrm{NCH}_{2} \mathrm{TMS}$ to $\alpha, \beta$-Unsaturated Cyclohexenones. Dual Reaction Pathways Based on Ion-Pair-Selective Cation-Radical Chemistry. J. Am. Chem. Soc. 1988, 110, 8099-8111. [CrossRef]

9. Yoon, U.C.; Mariano, P.S. Mechanistic and Synthetic Aspects of Amine-Enone Single Electron Transfer Photochemistry. Acc. Chem. Res. 1992, 25, 233-240. [CrossRef]

10. Mangion, D.; Arnold, D.R. Photochemical Nucleophile-Olefin Combination, Aromatic Substitution Reaction. Its Synthetic Development and Mechanistic Exploration. Acc. Chem. Res. 2002, 35, 297-304. [CrossRef]

11. Ohashi, M.; Nakatani, K.; Maeda, H.; Mizuno, K. Photochemical Monoalkylation of Propanedinitrile by Electron-Rich Alkenes. Org. Lett. 2008, 10, 2741-2743. [CrossRef] [PubMed]

12. Ohashi, M.; Nakatani, K.; Maeda, H.; Mizuno, K. Photoinduced Tandem Three-Component Coupling of Propanedinitrile, 2,5-Dimethylhexa-2,4-diene, and Cyanoarenes. J. Org. Chem. 2008, 73, 8348-8351. [CrossRef] [PubMed]

13. Yoshimi, Y. Photoinduced electron transfer-promoted decarboxylative radical reactions of aliphatic carboxylic acids by organic photoredox system. J. Photochem. Photobiol. A Chem. 2017, 342, 116-130. [CrossRef]

14. Maeda, H.; Takayama, H.; Segi, M. Photoinduced three-component coupling reactions of electron deficient alkenes, dienes and active methylene compounds. Photochem. Photobiol. Sci. 2018, 17, 1118-1126. [CrossRef] [PubMed]

15. Pandey, G.; Reddy, G.D.; Chakrabarti, D. Stereoselectivity in the photoinduced electron transfer (PET) promoted intramolecular cyclisations of 1-alkenyl-2-silyl-piperidines and -pyrrolidines: Rapid construction of 1-azabicyclo [m.n.0] alkenes and stereoselective synthesis of $( \pm$ )-isoretronecanol and ( \pm )-epilupinine. J. Chem. Soc. Perkin Trans. 1 1996, 219-224. [CrossRef]

16. Heinemann, C.; Demuth, M. Short Biomimetic Synthesis of a Steroid by Photoinduced Electron Transfer and Remote Asymmetric Induction. J. Am. Chem. Soc. 1999, 121, 4894-4895. [CrossRef]

17. Asaoka, S.; Kitazawa, T.; Wada, T.; Inoue, Y. Enantiodifferentiating Anti-Markovnikov Photoaddition of Alcohols to 1,1-Diphenylalkenes Sensitized by Chiral Naphthalenecarboxylates. J. Am. Chem. Soc. 1999, 121, 8486-8498. [CrossRef] 
18. Bertrand, S.; Hoffmann, N.; Humbel, S.; Pete, J.P. Diastereoselective Tandem Addition-Cyclization Reactions of Unsaturated Tertiary Amines Initiated by Photochemical Electron Transfer (PET). J. Org. Chem. 2000, 65, 8690-8703. [CrossRef]

19. Asaoka, S.; Wada, T.; Inoue, Y. Microenvironmental Polarity Control of Electron-Transfer Photochirogenesis. Enantiodifferentiating Polar Addition of 1, 1-Diphenyl-1-alkenes Photosensitized by Saccharide Naphthalenecarboxylates. J. Am. Chem. Soc. 2003, 125, 3008-3027. [CrossRef]

20. Bauer, A.; Westkämper, F.; Grimme, S.; Bach, T. Catalytic enantioselective reactions driven by photoinduced electron transfer. Nature 2005, 436, 1139-1140. [CrossRef]

21. Ma, N.; Shi, W.; Zhang, R.; Zhu, Z.; Jiang, Z. Study on improved diastereoselectivity in photo-induced electron transfer pinacol coupling reactions of substituted acetophenones. Tetrahedron Lett. 2011, 52, 718-720. [CrossRef]

22. Mizuno, K.; Ikeda, M.; Otsuji, Y. Dual Regioselectivity in the Photoallylation of Electron-Deficient Alkenes by Allylic Silanes. Chem. Lett. 1988, 17, 1507-1510. [CrossRef]

23. Hayamizu, T.; Ikeda, M.; Maeda,H.;Mizuno, K. Photoallylation and Photoreduction of Cyclohexylidenepropanedinitrile by Use of Allyltrimethylsilane via Photoinduced Electron Transfer: Control of the Product Ratio Depending on $\mathrm{p} K_{\mathrm{a}}$ Values of Additives. Org. Lett. 2001, 3, 1277-1280. [CrossRef]

24. Mizuno, K.; Hayamizu, T.; Maeda, H. Regio- and stereoselective functionalization of electron-deficient alkenes by organosilicon compounds via photoinduced electron transfer. Pure Appl. Chem. 2003, 75, 1049-1054. [CrossRef]

25. Hayamizu, T.; Maeda, H.; Ikeda, M.; Mizuno, K. Highly stereoselective carbon-functionalization of electron-deficient arylalkenes by use of organosilicon compounds via photoinduced electron transfer. Tetrahedron Lett. 2001, 42, 2361-2364. [CrossRef]

26. Hayamizu, T.; Maeda, H.; Mizuno, K. Diastereoselective Protonation on Radical Anions of Electron-Deficient Alkenes via Photoinduced Electron Transfer. J. Org. Chem. 2004, 69, 4997-5004. [CrossRef] [PubMed]

27. Maeda, H.; Nishitsuji, N.; Mizuno, K. Diastereoselective protonation on a radical anion in the photoallylation and photoreduction of 1,1-dicyano-2-methyl-3-phenyl-1-butene by allyltrimethylsilane. Res. Chem. Intermed. 2010, 36, 577-585. [CrossRef]

28. Dinnocenzo, J.P.; Farid, S.; Goodman, J.L.; Gould, I.R.; Todd, W.P.; Mattes, S.L. Nucleophile-Assisted Cleavage of Silane Cation Radicals. J. Am. Chem. Soc. 1989, 111, 8973-8975. [CrossRef]

29. Dockery, K.P.; Dinnocenzo, J.P.; Farid, S.; Goodman, J.L.; Gould, I.R.; Todd, W.P. Nucleophile-Assisted Cleavage of Benzyltrialkylsilane Cation Radicals. J. Am. Chem. Soc. 1997, 119, 1876-1883. [CrossRef]

30. de Lijser, H.J.P.; Snelgrove, D.W.; Dinnocenzo, J.P. Nucleophilic Substitutions on Silane Cation Radicals: Stepwise or Concerted? J. Am. Chem. Soc. 2001, 123, 9698-9699. [CrossRef] [PubMed]

31. Yamamoto, Y.; Nishii, S.; Ibuka, T. Acyclic Stereocontrol via an Electron-Transfer Process. Remarkable Stereochemical Difference between One- and Two-Electron Events. J. Am. Chem. Soc. 1988, 110, 617-618. [CrossRef]

32. Yamamoto, Y.; Nishii, S.; Ibuka, T. Diastereofacial Selection in the Conjugate Reduction of $\gamma$-Alkyl- $\alpha$, $\beta$-Unsaturated Carbonyl Derivatives. Stereocontrol Dictated by Aromatic Ring-Pd Interaction. J. Chem. Soc. Perkin Trans. 1 1989, 1703-1705. [CrossRef]

33. Paddon-Row, M.N.; Rondan, N.G.; Houk, K.N. Staggered Models for Asymmetric Induction: Attack Trajectories and Conformations of Allylic Bonds from ab Initio Transition Structures of Addition Reactions. J. Am. Chem. Soc. 1982, 104, 7162-7166. [CrossRef]

34. Texier-Boullet, F.; Foucaud, A. Knoevenagel condensation catalysed by aluminum oxide. Tetrahedron Lett. 1982, 23, 4927-4928. [CrossRef]

35. Kozik, B.; Wilamowski, J.; Góra, M.; Sepiol, J.J. Synthesis of $\alpha$-arylnaphthalenes from diphenylacetaldehydes and 1, 1-diphenylacetones. Tetrahedron 2008, 64, 6452-6460. [CrossRef]

36. Henze, H.R.; Leslie, W.B. Synthesis of 5-Benzohydryl-5-Substituted Hydantoins. J. Org. Chem. 1950, 15, 901-907. [CrossRef]

Sample Availability: Samples of the compounds are not available from the authors. 